\title{
INVESTMENT ATTRACTIVENESS OF UKRAINIAN AGRARIAN SECTOR
}

\author{
N. V. BONDARENKO, candidate of economic sciences \\ S. A. VLASIUK, candidate of economic sciences \\ Uman National University of Horticulture
}

T. A. DERKACH, candidate of economic sciences

Separate Structural Department of "Uman Vocational College of Technologies and Business of Uman National University of Horticulture"

У статті розглядаються проблеми інвестииійної привабливості аграрного сектору в Україні. Проаналізовано широкий спектр факторів, які виходять за межі аграрної політики, зокрема, макроекономічної політики. Викладено рейтинг інвестиційної привабливості аграрних галузей. Визначено комплексну стратегію підвищення інвестиційної привабливості України, яка включає ряд компонентів у контексті підтримки та розвитку як поточних порівняльних переваг економічної системи, так і майбутніх, щзо відповідають світовим тенденціям економічного розвитку та забезпечують принципи економічної безпеки України .

Ключові слова: інвестиції, інновації, інвестиційна привабливість, капітальні вкладення, фінансові ресурси, аграрний сектор.

Problem statement. The efficiency of economic activity provides a sufficient level of investment support. Investments contribute to the diffusion of innovation, stimulate the growth of production, economic and social development. They can be a source not only of funds, but also of new technologies, management skills and marketing systems. These resources, in turn, stimulate competition, innovation, capital accumulation and thereby create workplaces and encourage economic growth. It is essential to solve the issue of improving the economic regulation of investment activity in the agricultural sector in order to ensure the formation of sustainable development of agricultural production, which should become the leader of modern economy and the paramount center of formation of the country's budget revenue and the guarantee of a high level of agricultural commodity producers.

Analysis of recent research and publications. Among scientists working on the problems of investment attractiveness of agricultural enterprises, it is appropriate to distinguish the successes of such scientists: Blank I. O., Heiets V. M., Danylyshyn B. M., Deineko L. V., Zahorodnii A. H., Kovalov V. V., Marmul L. O., Makarii N. P., Sabluk P. T., Topikha V. I., Filippova S. V. and others. However, these studies do not show a long process of transformation the agricultural sector, which requires further analysis to assess investment attractiveness of this sector.

Research methodology. Theoretical and methodological basis of the study were the works of scholars of native and foreign practice, advanced scientists and 
practitioners worked on the investment attractiveness of the Ukrainian agricultural sector. General theoretical methods were used during scientific work. The methods of analysis were used in the study of the most popular factors influencing investment in the agrarian sector of Ukraine. With the help of abstract-logical method, the conclusions and proposals concerning the priority directions of investing in the country's agriculture are substantiated and presented.

Research results. Attracting investment in agriculture relies on a broad set of factors that go beyond agricultural policies, in particular macroeconomic policies. Consistent policy is a critical component of a favorable investment climate for all domestic or foreign investors. Figure 1 depicts the factors influencing the investment attractiveness of Ukrainian agrarian sector.

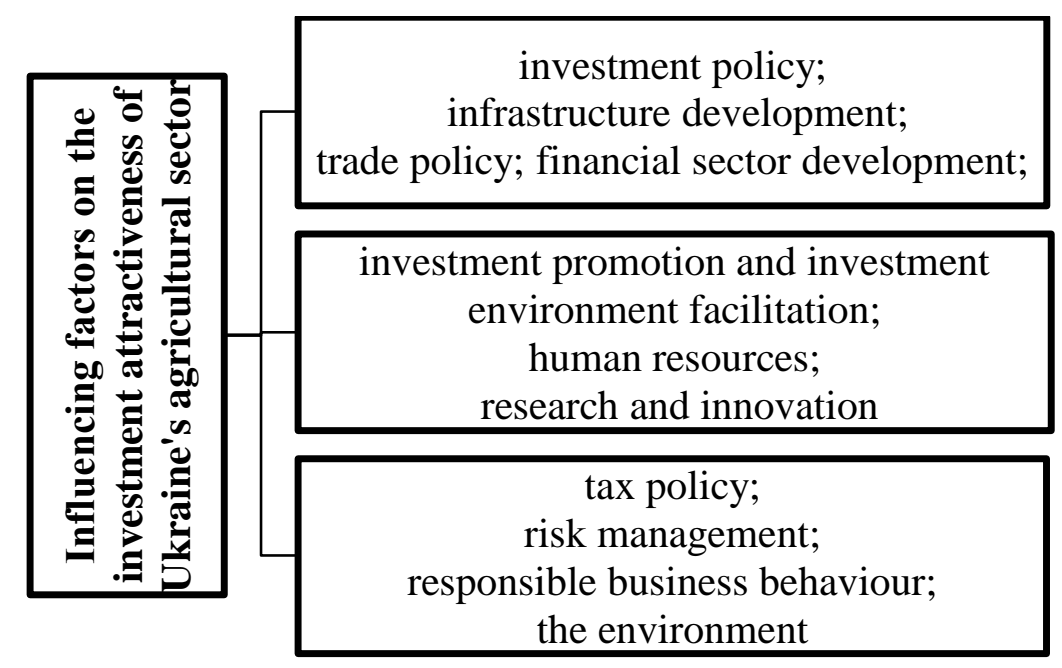

\section{Fig. 1. Factors influencing investment in Ukrainian agricultural sector [1]}

Investment and innovation development of agriculture is an active profound process, which task is an effective consumption of financial resources, attracting additional sources of funding, the search for potential investors are interrelated with the generation of new knowledge and ideas, technological development of new scientific discoveries, inventions and developments; implementation of innovations, selection of the best modern forms of organization and management of production. Investment attractiveness is one of the most topical and frequently used concepts in economics today. Not only a project or an enterprise can be attractive, i.e. profitable from the point of view of investment, but also any sector [2]. The investment attractiveness of the agricultural sector varies significantly depending on their location, which is related to natural and climatic conditions, the ecological condition of the area, etc. The assessment of investment attractiveness is one of the main indicators that an investor is guided by wile selecting an investment project, as it allows to meaningfully assess the condition of the sector, and is determined as a result of a thorough economic analysis of the state of enterprises in the regions and the country as a whole.

In January-September 2020, companies and organizations of Cherkasy region at the expense of all sources of funding have developed 4.7 billion capital investments, which is $39.5 \%$ less than the amount of capital investments for the corresponding 
period in 2019. The decline in capital investment was recorded in industrial enterprises $-66.8 \%$, agriculture, forestry and fisheries $-42.2 \%$. Figure 2 shows the total amount of investment in the Ukrainian economy.

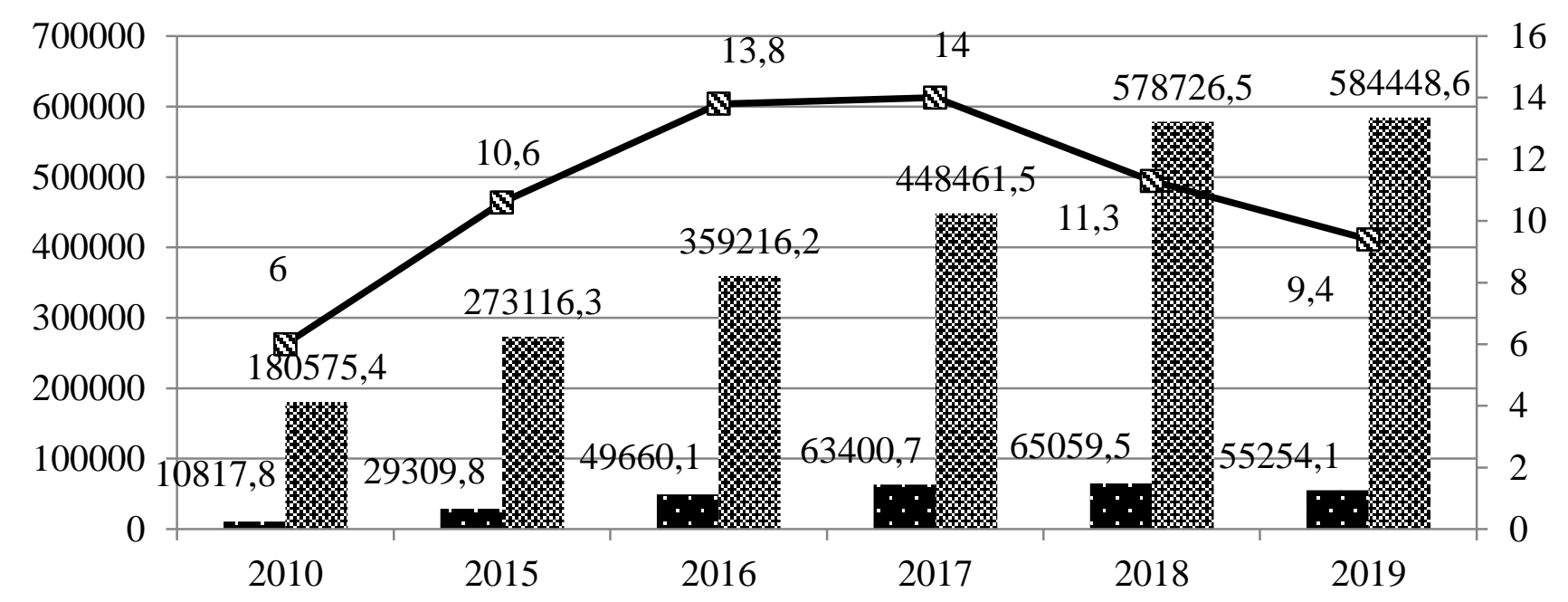

Capital investment in the agricultural sector, UAH mln Capital investment in the economy, UAH mln

$-\$-$ Share of investment in the agricultural sector, \%

\section{Fig. 2. Rate of capital investment in the Ukrainian economy [3]}

Currently in Ukraine there is an increasing of investment in the agricultural sector. The total amount of funds raised in January-March 2019 was 10.9 billion UAH, an increase of $57.9 \%$ compared to 2018 . Per 1 hryvnia of capital investment in food and tobacco production in January-March 2019, there was 3.38 hryvnia of investment in the agricultural sector. According to scientists' predictions of Institute of Agrarian Economics, the pace of 2018 and the first quarter of 2019 allowed to increase the total capital investment from 49700000000, to 75+ billion UAH [4].

Observing the amount of foreign investment (equity) contributed to the Ukrainian economy since the beginning of investment, which has been fluctuating as indicated above, and has been gradually increasing since 2017. Hence, as at December 1, 2020 the amount was USD 35809 million. This is $8.0 \%$ more than at the beginning of 2019. Most direct foreign investment comes to Ukraine from the European Union countries, as on December 1, 2020 consisted to $79.0 \%$ of total equity capital (28289 million USD), from other countries of the world $-21.0 \%$ (7520, 3 million USD) (Fig. 3) [5]. According to the rating estimation of investment attractiveness of the agricultural sector by means of rating assessments, the agricultural sector in Kyiv and Kyiv region ranks the first place in terms of investment attractiveness in Ukraine.

As for the second, third and fourth places, they are shared by the Zaporizhzhya, Dnipropetrovsk and Poltava regions. The agricultural sector in Volyn, Rivne, Ternopil, Chernivtsi, Zakarpattia, Zhytomyr and Chernihiv oblasts is least interested in foreign investors. 


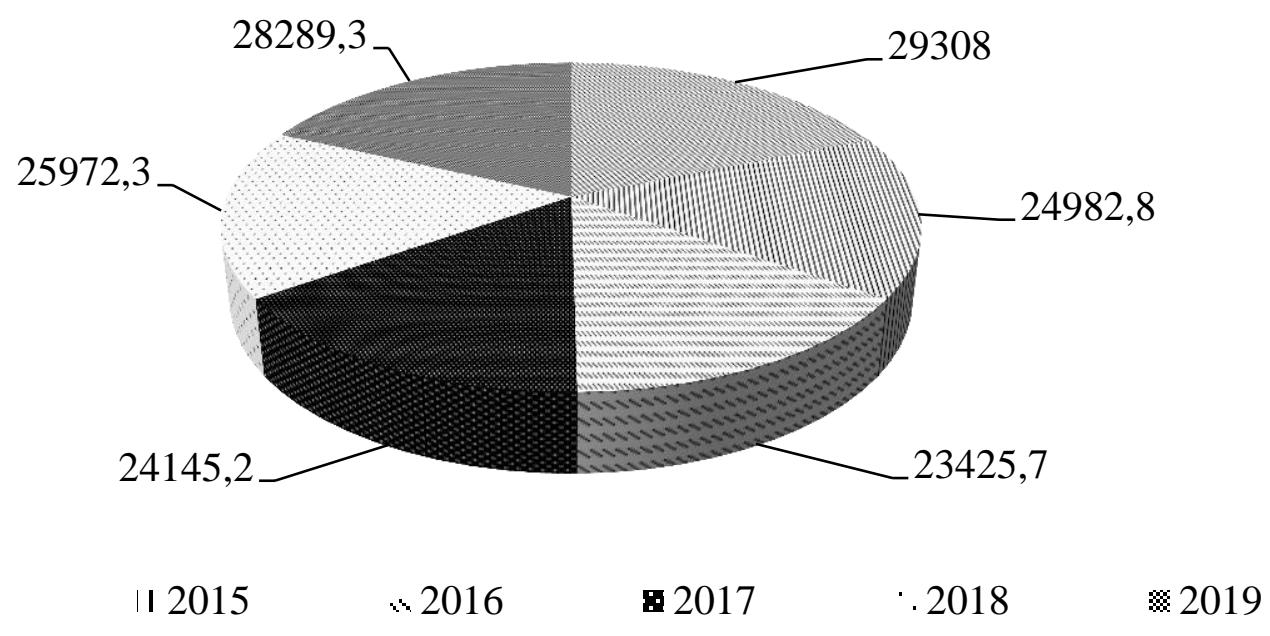

Fig. 3. Direct foreign investment (equity capital) in Ukraine from EU countries (levels of investment are cumulative since the beginning of investment) by year, USD million [5]

This trend is explained by the fact that these regions are not sufficiently favorable for agricultural production, natural and climatic conditions, insignificant area of irrigated land and, in addition, remote from the basic foreign markets of agricultural products [6]. As a result, the areas with low development potential and a high risk of loss of resources are not investment attracting.

Graphically, the structure of direct foreign investment in Ukrainian economy at the beginning of 2020 is demonstrated in figure 4. It should be noted that the share of investments in financial and insurance activities decreased significantly over 10 years (by $10.3 \%$ ). During these years, it has decreased from $23.0 \%$ in 2010 to $12.7 \%$ at the beginning of 2020 .
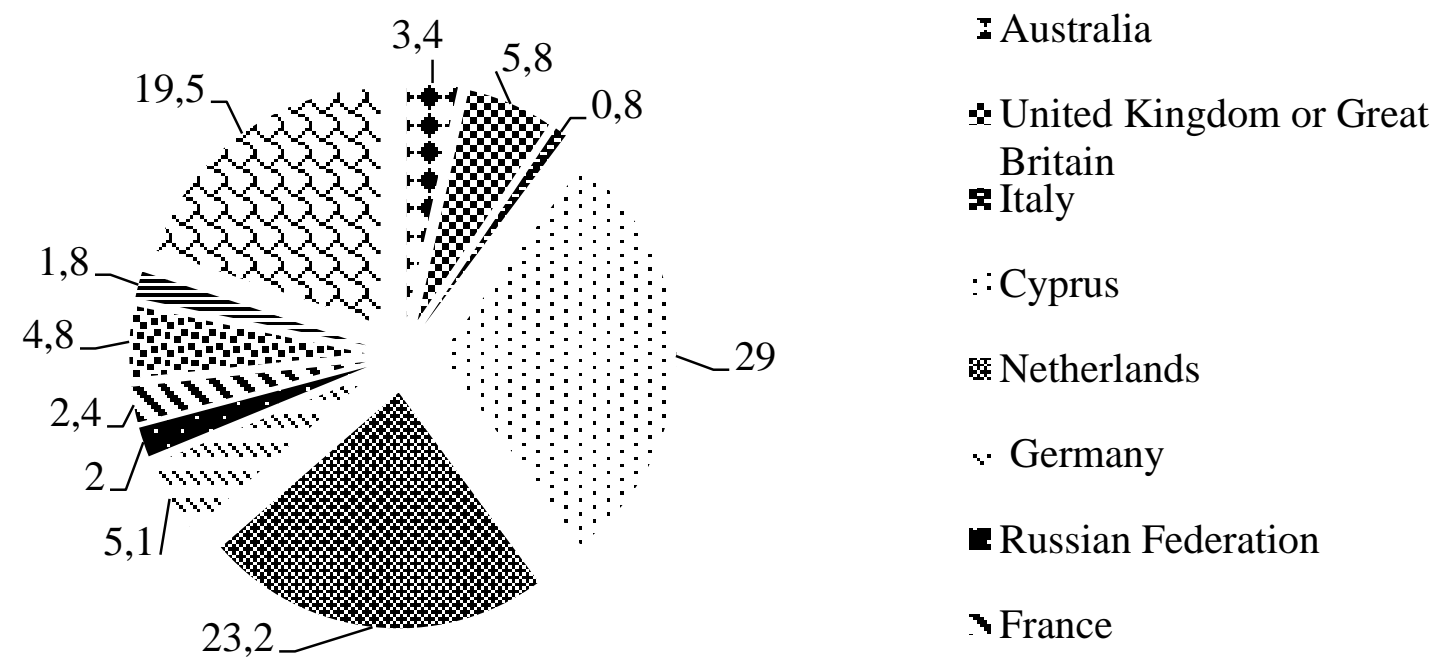

\section{Fig. 4. Geographical structure of direct foreign investment in Ukrainian economy as at January 1, 2020 [5]}

It should also be noted that only $1.5 \%$ of foreign investment was invested in the agricultural sector, an area in which Ukraine offers important investment projects [7]. According to the types of economic activity, by the beginning of 2020 the structure of 
direct foreign investment in Ukrainian economy is graphically demonstrated in Figure 5.

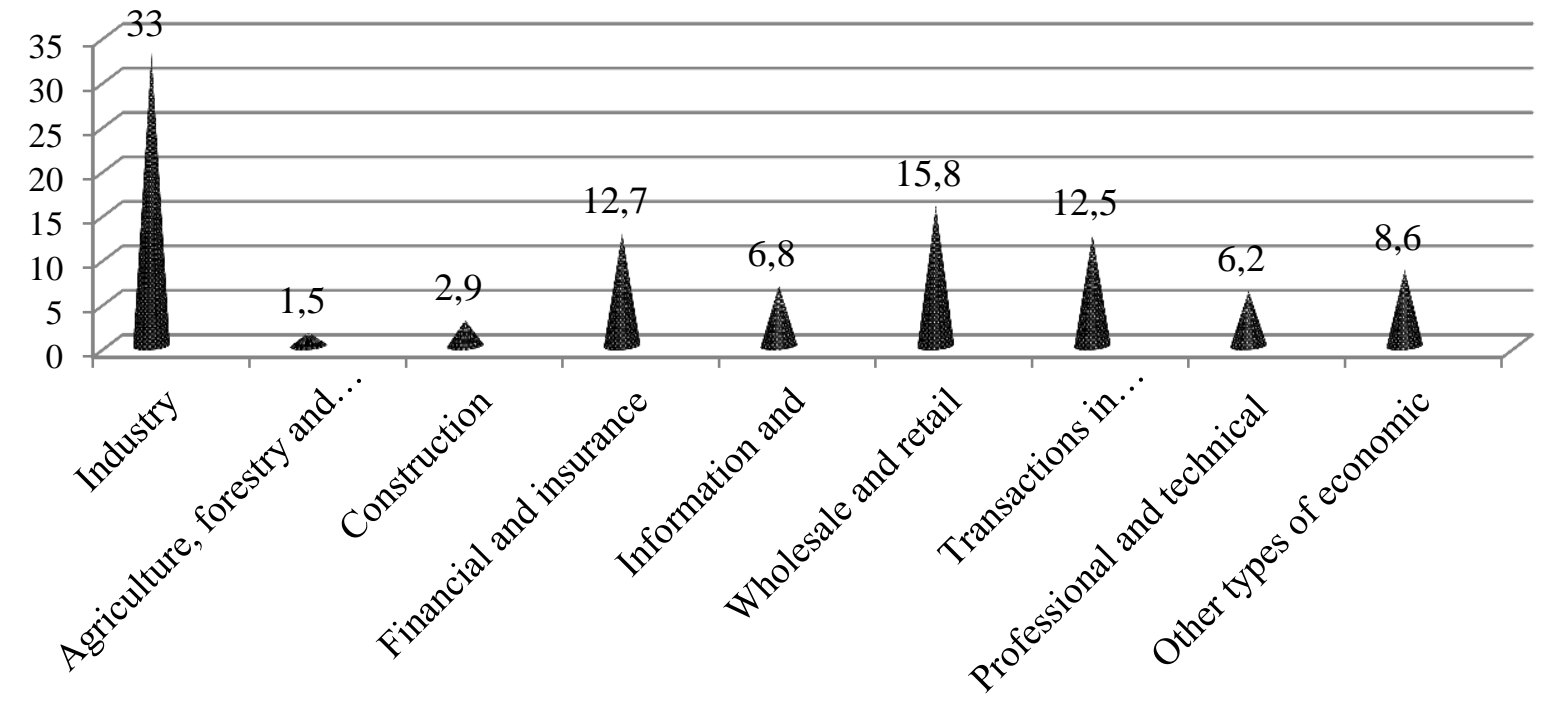

\section{Fig. 5. Structure of direct foreign investments in Ukrainian economy by economic activity as of 01.01.2020 [5]}

At present, the priority area for investment in agriculture should be updating and modernization of agricultural equipment. In fact, it is necessary to carry out technical re-equipment and reconstruction of livestock farms and complexes, to update the vehicles with high-quality, modern machines of the new generation. Thus, the result will be that the field works will be carried out with high quality and within the specified agro-technical terms which will ensure stable yields. A promising direction of investment activity at the enterprises of agro industrial complex is the use of progressive energy-saving technologies of crop growing aimed at saving resources and storage and increasing soil fertility at a sufficient level of yield [8].

Conclusions. It is necessary to create a comprehensive strategy for increasing the investment attractiveness of Ukraine, including a number of aspects in the context of supporting and developing both current comparative advantages of the economic system and promising ones, corresponding to the trends of global economic development and providing the foundations of Ukrainian economic safety. As for the state regulation of direct foreign investment in Ukraine, it should be noted that it is still in the process of formation, which is due to trends in the global economy and the processes and transformations taking place within the country. The modernization of the native economy states fundamentally new challenges to centralization and decentralization of state functions in the regulation of foreign investment, that includes the voluntary transition a part of the state's powers to both local and supranational levels of regulation.

The first step in restoring investment attractiveness is the adoption of the law on state support for investment projects with substantial investments. It provides the support to Ukrainian and foreign investors, whose investments are higher than 30 million euros and create over 150 jobs with an average salary $15 \%$ higher than in this region. These investors will have a direct contract with the government. Additionally, these investors will receive an investment manager, who will guide them from the 
beginning of the project to its outcome. Investors will also receive up to $30 \%$ of the cost of the investment with different sets of incentives. For example, these could be fiscal incentives.

\section{Лiтература}

1. Халатур С. М. Інвестиційна привабливість галузі сільського господарства України 3 урахуванням факторів ризику. у. URL: http://www.vestnik-econom.mgu.od.ua/journal/2017/24-1-2017/15.pdf (дата звернення: 04.04.2021).

2. Ткаченко С. С. Аналіз інвестиційної діяльності в аграрному секторі України, визначення факторів та шляхів іï активізації. Економіка та суспільство. 2021. Вип. № 23. URL: file:///C:/Users/ASER/Downloads/138$\% \mathrm{D} 0 \% \mathrm{~A} 2 \% \mathrm{D} 0 \% \mathrm{~B} 5 \% \mathrm{D} 0 \% \mathrm{BA} \% \mathrm{D} 1 \% 81 \% \mathrm{D} 1 \% 82 \%$ (дата звернення: 10.04.2021).

3. Статистична інформація про інвестиційну діяльність сільського господарства, лісового та рибного господарства. Державна служба статистики України. 2019. URL: http://www.ukrstat.gov.ua/ (дата звернення: 04.04.2021).

4. Вернер I. Є. Статистичний щорічник України: статистичний збірник. URL: http://www.ukrstat.gov.ua.

5. Офіційний сайт Державного комітету статистики України. URL: http://www.ukrstat.gov.ua (дата звернення: 04.04.2021).

6. Кремень О. І., Куберка В. І. Основи оцінки інвестиційної привабливості регіону. 2016. № 4. С. 62-66.

7. Михайленко О. Г., Красникова Н. А. Вплив іноземних інвестицій на розвиток економіки України в умовах глобалізації. Ефективна економіка. 2020. № 7. URL: http://www.economy.nayka.com.ua/?op=1\&z=8046 (дата звернення: 14.04.2021). (in Ukrainian)

8. Чернега О. Б., Білозубенко В. С., Іваненко І. А. та ін. Міжнародна економічна діяльність України: навч. посібник. Львів: Магнолія, 2017. 135 с.

\section{References}

1. Khalatur, S. M. (2017). Investment attractiveness of the agricultural sector of Ukraine taking into account risk factors. URL: http://www.vestnikeconom.mgu.od.ua/journal/2017/24-1-2017/15.pdf (Accessed 4 April 2021).

2. Tkachenko, S. Ye. (2021). Analysis of investment activity in the agricultural sector of Ukraine, determination of factors and ways of its activation. Economy and society, vol. 23. URL: file://C:/Users/ASER/Downloads/138\%D0\%A2\%D0\%B5 (Accessed on 10th April 2021).

3. Statistical information on investment activity in agriculture, forestry and fisheries (2019). State Statistics Service of Ukraine. Kyiv. URL: http://www.ukrstat.gov.ua/ (Accessed on 04th April 2021).

4. Verner, I. Ye. Statistical yearbook of Ukraine: statistical collection. URL: http://www.ukrstat.gov.ua. (Accessed on 05th April 2021). 
5. Official website of the State Statistics Committee of Ukraine. URL: http://www.ukrstat.gov.ua (Accessed on 04th April 2021).

6. Kremen, O. I., Kuberka, V. I. (2016). Basics of assessing the investment attractiveness of the region, no. 4, pp. 62-66.

7. Mykhailenko, O. H., Krasnykova, N. A. (2020). The impact of foreign investment on the development of Ukraine's economy in the context of globalization. Efficient economy, no. 7. URL: http://www.economy.nayka.com.ua/?op=1\&z=8046 (Accessed on 14th April 2021). (in Ukrainian).

8. Cherneha, O. B., Bilozubenko, V. S., Ivanenko, I. A. et al (2017). International economic activity of Ukraine. Lviv: Mahnoliia, 135 p. (in Ukrainian)

\section{Аннотация}

\section{Бондаренко Н. В., Власюк С. А., Деркач Т. А.}

\section{Инвестиционная привлекательность аграрного сектора Украины}

Определено, что привлечение инвестииий в сельское хозяйство опирается на широкий набор факторов, которые выходят за рамки аграрной политики, в частности макроэкономической политики. Данная последовательная политика, является важнейшим компонентом благоприятного инвестиционного климата для всех отечественных или иностранных инвесторов. Сформулировано определение инвестиционной привлекательности которая является одним из самых актуальных и часто используемых в экономике понятий сегодня. Установлено, что на 1 гривну капитальных инвестииий на осуществление изготовления пищевых продуктов и табачных изделий в январе-марте 2019 пришлось 3,38 грн инвестиций в аграрный сектор.

Изложены рейтинговые оценки инвестиционной привлекательности аграрной отрасли, агропромышленный комплекс в г.. Киев и Киевской области занимает первое место по инвестиционной привлекательности в Украине; вторых, третьих и четвертое места, разделяют Запорожская, Днепропетровская и Полтавская области. Следует отметить, что за 10 лет существенно уменьшалась доля инвестиций в финансовую и страховую деятельность.

Исследована мировой $u$ отечественный опьт, $u$ установлено эффективное реформирование аграрного сектора экономики происходит на основе активизации инвестииионной деятельности и существенного увеличения объема инвестииий. Определено, что в период ограниченности инвестиционных ресурсов на государственном уровне инвестиционная привлекательность региона является базовым критерием, на основе которого формируются инвестиционная стратегия и инвестиционная политика предприятий и государства в целом. В связи с этим особую актуальность приобретает вопрос рассмотрения главных оснований инвестиционной деятельности отдельных регионов и определения многообещающие путей привлечения ресурсов.

Определено, что в настоящее время приоритетным направлением инвестирования в сельское хозяйство должно быть обновление и модернизация 
сельскохозяйственной техники. То есть, нужно осущуествить техническое перевооружение и реконструкцию животноводческих ферм и комплексов, обновить парк качественными, современными машинами нового поколения. Нужно сформировать комплексную стратегию повышения инвестиционной привлекательности Украины, включающуая ряд элементов в контексте поддержки и развития как текуших сравнительных преимуществ экономической системы, так и перспективных, соответствуют тенденциям развития глобальной экономики и обеспечивают обеспечения основ экономической безопасности Украины. Предложено, что первым шагом для восстановления привлекательности инвестирования должно стать принятие Закона о государственной поддержке инвестиционных проектов со значительными инвестициями.

Ключевые слова: инвестиции, инновации, инвестиционная привлекательность, капитальные инвестиции, финансовые ресурсы, аграрный сектор

\section{Annotation}

\section{Bondarenko N. V., Vlasiuk S. A., Derkach T. A.} Investment attractiveness of Ukrainian agrarian sector

The article deals with the problems of investment attractiveness of the agricultural sector in Ukraine. It is defined that engaging investment in agricultural sector is based on a wide range of aspects that go beyond agricultural policy, in particular macroeconomic policy. Such coherent policy is an essential part of a beneficial investment climate for both native and foreign investors.

The definition of investment attractiveness has been determined that is one of the most relevant and frequently used in economy today. It was found that for UAHI of capital investment for the manufacturing of food and tobacco products in JanuaryMarch 2019, UAH 3, 38 was accounted for agricultural sector.

Rating of investment attractiveness of agrarian branches is stated. It is outlined that Kyiv and Kyiv region agro-industrial complex is ranked the first position as well as the second, third and fourth positions are shared by Zaporizhia, Dnipropetrovsk and Poltava regions. It should be noted that over 10 years the share of investments in financial and insurance activities has significantly decreased.

The foreign and native experience has been studied, and an effective transformation of the agrarian sector of economy has been established that is based on the intensification of investment activities and a significant increase in the levels of investment. It has been determined that during the period of constrained investment resources at the state level, the investment attractiveness of the region is the key requirement through which the investment strategy and investment policy of enterprises and the state as a whole are formed. Consequently, the issue of increasing relevance becomes the investment activity of individual regions and identifying promising ways to attract resources. 
It was determined that nowadays the priority area for investment in agriculture should be updating and modernization of agricultural equipment. Therefore, it is necessary to carry out technical re-equipment and reconstruction of livestock farms and complexes, to update the vehicles with high-quality, modern machines of the new generation.

It is necessary to create a comprehensive strategy for increasing the investment attractiveness of Ukraine, which includes a number of aspects in the context of support and development of both the current comparative advantages of the economic system and the prospective ones, correspond to the development trends of the global economy and provide the foundations of Ukraine's economic safety.

It is proposed that the first step in restoring investment attractiveness is the adoption of the law on state support for investment projects with substantial investments.

Keywords: investments, innovations, investment attractiveness, capital investments, financial resources, agrarian sector

\section{ФОРМУВАННЯ ІННОВАЦІЙНОГО ПРОЕКТУ ШЛЯХОМ ПРИЙНЯТТЯ ЕФЕКТИВНИХ УПРАВЛІНСЬКИХ РІШЕНЬ}

С. Ю. СОКОЛЮК, доктор економічних наук

I. І. ЧЕРНЕГА, доктор економічних наук

О. В. ЖАРУН, кандидат економічних наук

М. А. КОРОТЕЕВ, кандидат економічних наук

О. С. ТУПЧІЙ, кандидат економічних наук

У статті розглянуто сутність та теоретичні засади формування інноваційного проекту. Досліджено, щуо під розумінням інноваційного проекту вважають складну систему взаємообумовлених $i$ взаємопов'язаних за ресурсами, термінами і виконавцями заходів, спрямованих на створення або впровадження окремого інноваційного продукту. Встановлено, що управлінське рішення виникає внаслідок виникнення певної проблеми, ухвалення рішення зумовлює виникнення відповідального за його реалізацію, відповідальність за наслідки ухваленого рімення вимагає розгляду альтернатив варіантів розв'язання проблеми з метою вибору найкращого.

Ключові слова: інновації, управління, проект, інноваційний продукт,інновачійна діяльність.

Постановка проблеми. Безсилля вітчизняного інноваційного розвитку спричинено, 3 одного боку, бездіяльністю держави (недосконалою законодавчою базою, відсутністю фінансової підтримки тощо), а 3 другого, внутрішніми суб'єктивними факторами підприємств (відсутністю вільних 